УДК 347.73

DOI https://doi.org/10.32837/yuv.v0i4.2227

А. Овчаренко,

кандидат юридичних наук, асистент кафедри фінансового права

Національного юридичного університету імені Ярослава Мудрого

\title{
ДО ПИТАННЯ ПРО РОЗВИТОК АЛЬТЕРНАТИВНИХ СПОСОБІВ ВИРІШЕННЯ ПОДАТКОВИХ СПОРІВ В УКРАЇ̈І
}

Проблеми податкового адміністрування з кожним роком набувають все більшої актуальності. Адже в період пандемії унаслідок економічного спаду як світової тенденції 2020-2021 років спостерігається збільшення масштабів ухилення від сплати податків, тоді як дохідні частини бюджетів скоротилися через зменшення ділової активності господарюючих суб'єктів і скорочення бази оподаткування з прибуткових податків.

Враховуючи специфіку податкових правовідносин, у котрих стикаються публічний і приватний інтереси, стає зрозумілим, що податковий спір за своєю природою передбачає високий ступінь конфліктності. Податковий спір $€$ різновидом публічно-правового спору, що виникає між учасниками податкових відносин, один з яких - суб'єкт владних повноважень із питань застосування норм податкового законодавства у сфері нарахування і сплати податків та зборів із метою реалізаціі та захисту прав і законних інтересів [1;49].

3 огляду на критичний стан завантаженості судової системи, зокрема адміністративних судів в Україні, гостро стоїть питання досудового вирішення податкових спорів. Глобалізація і тенденції з активної імплементації в Україні європейської практики вирішення спорів вимагають упровадження сучасних економічно-ефективних методів вирішення податкових спорів, які розвантажать адміністративні суди.
Аналіз сучасних наукових публікацій і досліджень із питань альтернативного вирішення податкових спорів свідчить, що нині не існує чіткого визначення i розуміння категорій, пов'язаних із темою дослідження. Зокрема, проблематика медіації стала предметом дослідження В. Баранова, О. Белінської, О. Бобрової, Я. Валюк, Л. Власової, О. Ващук, А. Гайдука, О. Горової, Ю. Губар, с. Задорожної, В. Землянської, Г. Єременка, О. Кармаз, В. Кудрявцева, Ю. Ліхолєтової, В. Маляренка, Т. Подковенка, Н. Прокопенка, К. Шершун, Д. Яніцької та інших. Окремі питання запровадження і розвитку альтернативних методів вирішення податкових спорів розглядали такі вітчизняні та зарубіжні науковці, як $M$. Кучерявенко, I. Бондаренко, Є.Смичок, О. Бучинський, $M$. Троянська та інші. 3 огляду на новизну явища та невизначеність у вітчизняній науці актуальність дослідження не викликає сумнівів.

Мета дослідження - визначення змісту, правової сутності, окремих різновидів альтернативних способів вирішення податкових спорів, зокрема медіації, а також перспектив розвитку прогресивних способів здійснення податкового контролю й аналіз міжнародного досвіду в цій copepi.

Останні роки у світі можна спостерігати активізацію практики застосування альтернативних процедур як інноваційного підходу до припинення 
юридичних спорів. Альтернативне вирішення спорів передбачає активне використання сторонами юридичного конфлікту стратегії компромісу з метою узгодження їх інтересів. Термін «альтернативне вирішення спорів» або АВC (від англ. «Alternative dispute resolution» або ADR) уперше почали застосовувати у США для позначення позасудових недержавних процедур на противагу судочинству. Нині цей термін широко застосовується в законодавстві багатьох країн.

Під альтернативним вирішенням спорів розуміють сукупність правомірних способів, спрямованих на врегулювання або вирішення юридичних спорів, які не належать до державного провадження (судовий та адміністративний порядок вирішення спорів). До основних альтернативних процедур відносять переговори, медіацію i третейський розгляд (арбітраж) [2, с. 25]. Водночас термін «альтернативне вирішення спорів» часто замінюють терміном «адекватне вирішення спорів» (від англ. «Appropriate dispute resolution»), а також терміном «ефективне вирішення спорів», або ЕВС (від англ. «Effective dispute resolution» чи EDR).

Альтернативне вирішення спорів - це припинення юридичних конфліктів (спорів) без винесення акта за результатами розгляду справи по суті в судовому або адміністративному порядку шляхом досягнення сторонами взаємоприйнятної угоди про врегулювання спору або шляхом прийняття обов'язкового рішення, що здійснюється на підставі добровільного волевиявлення сторін та за правилами, які самостійно встановлюються сторонами [3].

Позасудовий механізм вирішення правових конфліктів, на відміну від судового, не має суворої процедурної регламентації і може здійснюватися як без участі, так і за участю третьої сторони. Застосування альтернативних способів урегулювання спорів є ознакою розвиненого грома- дянського суспільства, високого рівня правової культури в державі.

Проте неналежна правова регламентація альтернативних способів вирішення спорів у нашій державі не дозволяє виділити в окремий правовий інститут такий спосіб розв'язання конфліктів, як системне утворення, що призводить до низького рівня практичного застосування таких способів, недовіри з боку учасників правовідносин до всіх способів урегулювання спорів, окрім судового й адміністративного.

Тому нині актуальним $€$ правове визначення видів альтернативного вирішення спорів, принципів і кола ї застосування, державних стандартів у цій сфері, закріплення гарантій ефективного застосування, що дозволить підвищити довіру учасників правовідносин до них.

Нині в Україні не існує спеціального законодавства, що регулює здійснення альтернативних способів вирішення спорів. Однак відповідно до ч. 4 ст. 55 Конституції України держава гарантує можливість кожному будь-якими не забороненими законом способами захищати свої права. Способи альтернативного вирішення спорів є одними з таких способів захисту прав.

Окрім того, враховуючи світові тенденції посилення ролі альтернативних способів вирішення спорів, у нашій державі останнім часом активізувалися законотворчі процеси в цій сфері. Зокрема, 19.05.2020 р. у Верховній Раді України було зареєстровано проект закону «Про медіацію» № 3504, який вже 15.07.2020 р. був прийнятий у першому читанні (далі-Проект Закону).

У Проекті Закону медіація визначається як добровільна, позасудова, конфіденційна, структурована процедура, під час якої сторони за допомогою медіатора (медіаторів) намагаються врегулювати конфлікт (спір) шляхом переговорів.

Сферою застосування медіації у ст. 2 Проекту Закону визначено 
будь-які конфлікти (спори), які виникають у цивільних, сімейних, трудових, господарських, адміністративних правовідносинах, а також кримінальних провадженнях під час укладання угод про примирення між потерпілим та підозрюваним, обвинуваченим, а також в інших сферах суспільних відносин [4]. Тобто перелік правовідносин, до яких може бути застосована процедура медіаціі, не є вичерпаним, а прямої заборони застосовувати норми до податкових правовідносин не встановлено.

Для успішного впровадження в Україні процедур податкової медіації, окрім першочергового прийняття Закону України «Про медіацію», слід зробити такі кроки, як: реалізація програми підготовки медіаторів, підвищення їх кваліфікації; активна популяризація через офіційні сайти держорганів процедури медіації під час вирішення податкових спорів; виділення спеціалізаціі податкових медіаторів; створення об'єднань медіаторів як самоврядних організацій; розроблення і прийняття Кодексу професійної етики медіаторів, внесення змін до Податкового кодексу України щодо можливості розв'язання податкового спору із застосуванням податкової медіаціі.

У зв'язку з цим альтернативні способи вирішення податкових спорів, серед яких $є$ медіація, сприятимуть розбудові взаємин на умовах рівноправності сторін спору і взаємовигідного співробітництва, за яким дотримуватимуться як публічні інтереси держави, так і приватні інтереси платника податків.

В останні роки у світовій практиці активно застосовується такий спосіб попередження виникнення податкових спорів, як горизонтальний податковий моніторинг - якісно новий рівень взаємодії між великими платниками податків і контролюючими органами, тому механізм його дії базується на попередженні порушень податкового законодав- ства, а не на ліквідації їніх наслідків і притягненні до відповідальності. Сутність нового способу полягає в підписанні податковими органами з великим платником податків угоди, яка передбачає, що платник податків повідомлятиме контролюючому органу інформацію про господарську операцію, що планується, і тільки після відповіді здійснюватиме господарську операцію. За горизонтального моніторингу відбувається постійний обмін інформацією між платником податків і контролюючими органами. Платник податків відкриває доступ до інформації про свою діяльність, повідомляє про всі можливі податкові ризики, що виникають під час прийняття тих чи інших рішень, а контролюючий орган оперативно надає свій висновок щодо податкових наслідків з огляду на чинне податкове законодавство. Отже, якщо прийняті платником податків рішення узгоджені 3 контролюючим органом, то немає необхідності у проведенні регулярних податкових перевірок. Це є взаємовигідною співпрацею: платник податків отримує визначеність із питань оподаткування, тобто мінімізує податкові ризики, а податковий орган витрачає менше матеріальних і трудових витрат на податкове адміністрування, адже у випадку застосування такого висновку платником податків контролюючий орган зобов'язується не здійснювати виїзну документальну перевірку щодо певного кола питань, які були попередньо узгоджені під час проведення горизонтального податкового моніторингу. Ці положення закріплюються угодою. Основна мета зазначених угод - взаємодія та інформаційний обмін, спрямовані на дотримання платниками податків законодавства про податки і збори, а також на підвищення передбачуваності податкового регулювання та якості адміністрування.

Термін «горизонтальний моніторинг» вперше почали використовувати податкові органи Нідерландів, 
керуючись рекомендаціями Наукової ради 3 державної політики (Scientific Council for Government Policy) у 2002 році, де зазначалося, що державі слід будувати свої відносини з платником податків на основі принципів взаємодії і прозорості бізнесових процесів [5, с. 348].

3 огляду на вищезазначене можна стверджувати, що горизонтальний моніторинг, 3 одного боку, сприяє посиленню і підвищенню ефективності податкового контролю за платниками, а 3 іншого - виступає превентивним заходом у боротьбі 3 податковими правопорушеннями, що дозволяє не застосовувати такий спосіб наступного контролю, як виїна податкова перевірка. Отже, можна виділити переваги цього методу як для податкового органу, так і для платника податків. Переваги для податкових органів є такі: високий ступінь відкритості платника податків; постійний доступ до документообігу господарських операцій в електронному режимі; скорочення кількості виїзних перевірок і пов'язаних 3 ними витрат; зменшення ризиків застосування великими платниками податків схем ухилення від податків. Серед переваг для платників податків можна зазначити такі: можливість заздалегідь узгоджувати позицію контролюючих органів щодо податкових наслідків господарських операцій, які плануються; зменшення невизначеності, що виникла під час тлумачення і застосування податкового законодавства; зниження податкових ризиків; можливість звільнення від виїзних податкових перевірок.

Для втілення процедури горизонтального моніторингу в Україні необхідна належна правова регламентація зазначеного способу здійснення контролю. Адже контролюючі органи, як і інші органи державної влади, діють виключно на підставі, в межах повноважень, у спосіб, що передбачають Конституція і закони України. Проте чинне податкове законодавство не передбачає право податкових органів на укладення з платниками податків договорів щодо здійснення горизонтального моніторингу.

Основна мета введення такого інституту полягає в побудові взаємовигідних відносин між податковим органом та платником податків, формування співпраці державних органів і суб'єктів господарювання. Результатом проведення процедури податкового моніторингу є мотивований висновок, який має відображати позицію податкового органу з питань правильності обчислення, повноти і своєчасності сплати податків і зборів за здійснення обумовленої господарської операції певного платника податків.

3 огляду на вищезазначене, не можна ставити знак рівняння між поняттями «медіація», «альтернативне вирішення податкових спорів», «горізонтальний податковий моніторинг», оскільки основною метою медіації у податкових відносинах загалом визнається прийняття стороннім суб'єктом рішення, що задовольняє інтереси обох сторін спору як контролюючого органу, так і платника податків. У разі застосування горизонтального податкового моніторингу спостерігається відсутність самого факту спору між платником податків і податковим органом. Можливо, внаслідок застосування процедури податкового моніторингу можна буде запобігти виникненню спору.

Проведенний аналіз доводить, що визнавати горизонтальний податковий моніторинг аналогом медіативних процедур не можна. Горізонтальний податковий моніторинг - інструмент ефективної взаємодії між податковим органом і платником податків, спрямований на запобігання вчиненню порушення податкового законодавства під час здійснення певної господарської операції, на виховання у платника податків правової культури. Цей інститут $€$ превентивною мірою в системі становлення 
податкової дисципліни. Слід відзначити, що вільне використання юридичної термінології, неточне їі трактування в рамках податкових відносин тягнуть за собою помилки правозастосовного характеру, тому зазначені категорії потребують суворої правової регламентації і деталізації у чинному законодавстві.

У статті досліджено перспективи запровадження альтернативних способів вирішення податкових спорів, визначено правову сутність окремих їх різновидів, зокрема медіаціï, а також визначено перспективу розвитку прогресивних способів здійснення податкового контролю $i$ співвідношення ичих категорій.

Проблеми податкового адміністрування з кожним роком набувають все більшої актуальності. Враховуючи специфіку податкових правовідносин, у котрих стикаються публічний $i$ приватний інтереси, стає зрозумілим, що податковий спір за своєю природою передбачає високий ступінь конфліктності. Податковий спір є різновидом публічно-правового спору, який виникае між учасниками податкових відносин, один із яких - суб'єкт владних повноважень. 3 огляду на критичний стан завантаженості судової системи, зокрема адміністративних судів в Україні, гостро стоїть питання досудового вирішення податкових спорів. Глобалізація $i$ тенденціi активної імплементації в Україні європейської практики вирішення спорів вимагають впровадження сучасних, економічно-ефективних методів вирішення податкових спорів, які розвантажать адміністративні суди. Крім того, нині потрібні нові методи податкового адміністрування $i$ способи здійснення податкового контролю. Горизонтальний податковий моніторинг - інструмент ефективної взаємодіі між податковим органом $і$ платником податків, орієнтований на запобігання вчиненню порушення податкового законодавства під час здійснення певної господарської операції, виховання у платника податків правової культури. Цей інститут є превентивною мірою в системі становлення податкової дисиципліни та за своєю сутністю не є аналогом медіаціï. у статті визначено, що наразі в Україні чинним законодавством не передбачено жодних альтернативних способів урегулювання податкових спорів. Виключні способи врегулювання податкових спорів передбачені в Податковому кодексі України, до них належить судовий та адміністративний порядок.

Автор дійщов висновку, що визнавати горизонтальний податковий моніторинг аналогом медіативних процедур не можна. Горізонтальний податковий моніторинг - інструмент ефективної взаємодії між податковим органом та платником податків, спрямований на запобігання вчиненню порушення податкового законодавства під час здійснення певної господарської операціï.

Ключові слова: податковий контроль, медіація, горизонтальний податковий моніторинг, альтернативні способи вирішення спорів, податковий спір.

\section{Ovcharenko A. On the develop-} ment of alternative ways of resolving tax disputes in Ukraine The article examines the prospects for the introduction of alternative ways of resolving tax disputes, determines the legal nature of some of their varieties, including mediation, as well as identifies the prospects for the development of progressive methods of tax control, analyzes international experience in this area. The tax dispute by its nature involves a high degree 
of conflict. Recently, the problems of tax administration have become especially relevant, since at the time of the intensification of the economic crisis. The tax dispute is a type of public law dispute that arises between participants in a tax relationship, one of which is a subject of power. Given the critical state of the judicial system, including administrative courts in Ukraine, the issue of pre-trial settlement of tax disputes is acute. Globalization and trends in the active implementation of European dispute resolution practice in Ukraine require the introduction of modern, cost-effective methods of resolving tax disputes, which will relieve administrative courts. In addition, there is now a clear need for new methods of tax administration and ways to exercise tax control.

Horizontal tax monitoring is a method for effective interaction between the tax authority and the taxpayer, aimed at preventing violations of tax legislation in carrying out a certain business transaction, education of the taxpayer's legal culture. This institution is a preventive measure in the system of tax discipline and in essence is not an analogue of mediation. It is determined that the current legislation in Ukraine does not provide for any of the alternative ways of settling tax disputes. Exceptional methods of settling tax disputes are provided for in the Tax
Code of Ukraine and include judicial and administrative procedures.

Successful application of this method of control in Ukraine requires a high level of trust of taxpayers in tax authorities, the appropriate level of legal culture of taxpayers, the necessary staff and level of professionalism of employees of tax authorities to ensure proper quality of such conclusions and deadlines.

Key words: tax administration, mediation, horizontal tax monitoring, alternative dispute settelement procedures, tax dispute.

\section{Література}

1. Бучинський О.Й. Особливості класифікації податкових спорів. Прикарпатський юридичний вісник. 2018. Bun. 4. T. 2. C. $48-52$.

2. Кармаз О. Iнститут медіаціï: основні концепції розвитку. Піәприємництво, господарство і право. 2017. № 2. C. 24-28.

3. Brookes D., McDonough I. The Differences between Mediation and Restorative Justice/Practice. URL: http://wrw. restorativejusticescotland.org.uk/ MedvsRJ-P.pdf

4. Проект Закону України «Про медіанію» № 3504 вї 19.05.2020. URL: http: / / w1.c1.rada.gov.ua/pls / zweb2 / webproc4_1?pf3511=68877

5. Троянская М.А. Горизонтальный налоговый мониторинг как инструмент совершенствования налогового администрирования. Азимут научных исследований: экономика и управление. 2017. № 3 (20). C. 347-350. 